peculiar sub-specific types found there are many of them nezo forms, which have arisen since the Mammoth age, having been altered from the old ones, which live on under old conditions in the West of Europe and the Japanese Archipelago.

I should like to specify one particular bird in regard to which this notion seems to point a special moral. This is the British red grouse, the only peculiar bird of these islands. Its nearest ally on the Continent, and a very near ally, is the willow grouse. I have little doubt that the willow grouse of the Continent is an altered form, and that our red grouse is the parent, since the evidence we have, and it is not slight, goes to show that England has preserved better than Scandinavia the cimatic conditions of the Mammoth period. The white marks and other characteristics of the willow grouse are evidences of the eff.ct of colder winterquarters, as they are in the case of the f,tarmigan.

Lastly, I cannot avoid emphasizing once more the couclusion which I have pressed in my book that this milder climate in siberia during the Mammoth age entirely does away with the neces,ity for invoking quite transcendental seasoval migrations for the fauna there which have been postulated by Prof. Dawkins and others. That the Mammoth, with its immature young, should be able to pass to and fro between the south of Siberia and the New Siberian Islands and Kamchatka, between summer and winter, has always seemed to me incredible. If they could compass the journey they would either find a temperate conditions of things, which is alone consistent with their finding food, when there would be no occasion for them to migrate, or they would find the conditions which prevail now, when no pachyderms could find food even in summer, since they are physically incapable of browsing the short herbage of the tundra. Nor could the trees and the southern mollusks, like the Cyrena, migrate, even if the young Mammoths could. This theory of migrations finds no support, so far as I know, among those who have studied the problem on the ground; and it is put entirely out of court when we realize that, Siberia having had a temperate climate, there was no necessity to migrate.

A similar argument applies to the theory invoking the transport of the Mammoth carcasses by means of the Siberian rivers, which has always seemed to me untenable when the conditions are faced. I would mention that in Baron Toll's recent journey to the New Siberian Islands, situated a long way north of the Siberian coast-line, and entirely out of the reach of any possible river portage, he not only found remains of a carcass of a Mammoth preserved in the flesh, but found them in a bed situated to the north of a ridge. This fact may be put beside those already mentioned by Wrangell and others long ago, that the carcasses and skeletons and cachés are found chiefly on the hillocks and higher ground of the tundra, out of the reach of river-floods altogether, and found most frequently near the small rivulets and feeders of the greater streams, which could not float them, and found also near those flowing south. This theory of portage and that of seasonal migrations have been nursed and maintained in this country in spite of evidence of every kind, because they are supposed in some way to buttress the theory of uniformity, as taught by Lyell and Ramsay. An appeal to them and to similar complicated physical causes becomes not merely unwarrantable, but unscientific and illogical, when we realize that from one end of Siberia to the other the climate was sufficiently temperate when the Mammoth lived there to enable trees to grow and vegetable food to be found everywhere, and the physical surroundings of the country were probably such as may be measured by those still prevailing in Britain or Japan.

Bentcliffe, Eccles, January Io.

$$
\text { HeNry H. Howorth. }
$$

\section{The Crystallization of Lake Ice.}

ON returning recently from North Wales, I was very pleased to meet with a description, by $\mathrm{Mr}$. James C. McConnel (NATURE, December 27, p. 203), of the elaborate experiments performed by himself and Mr. Dudley A. Kidd on glacier and lake ice at St. Moritz. An experiment I had made on the ice of Llyn Creigenen, a small lake to the north-west of Tyrau Mawr, seems to me to be, in some measure, confirmatory of the results obtained in connection with the crystallization of lake ice.

By sharply striling the ice, which was only about half an inch thick, with the rounded end of a stick, fractures were produced, which invariably adopted the form of a six-rayed star-like figure. The beantifu' regularity of these figures, in regard to the num- ber, position, and perfect straightness of their rays, at once remincled me of the well-known percussion- and pressurefigures produced in mica plates by Reusch and Bauer. Mr. Grenville Cole, who was with me at the time, repeated the experiment, and obtained precisely similar results. We found that over a certain area a large number of these figures could be produced, in each of which there were corresponding parallel rays-that is to say, every percussion-figure was similarly disposed with regard to a fixed line. Outside this area, the figures produced, although preserving the characters of those first made, exhibited a change in the direction of the rays. In this way we could determine the boundaries of a number of adjacent areas, sepurated from one another by refinite lines of demarcation. $1 \mathrm{~h}: \mathrm{se}$ areas averaged about two feet across.

We were unable to conceive of any conditions of stress which woulh, in a homogeneous solid pla:e, give rive to such phenomena - fractures of such beautiful regularity, and so constant in character. Consequently, we thought of crystallization; but this wisuld necessitate the recognition of ice-crystals of very large dimensions - a conclusion obviously at variance with the existing notions concerning the crystalline characters of ice. We thought, however, that the matter might be worthy of investigation, and, on returning to town, were 'pleased to find that large crystals of lake ice had been found at St. Moritz by Messrs, McConnel and Kidd, which, however, did not attain the size of those we noticed on Llyn Creigenen. But the fact that on the St. Moritz Lake the ice attained a thickness of over one foot shows that the temperature must have been lower, and the conditions more rigorous, than in North Wales at the time of our visit.

If it is possible at all to obtain large crystals of ice, I should say the conditions for such on Llyn Creigenen were of the most favourable character. For three days previously, the temperature varied very little from zero $\mathrm{C}$., and, from the slight wind that prevailed at the time, the lalie was well sheltered by the hills which rise abruptly around ; indeed, the lake was unusually free from disturbing influences of any kind.

If these sheets of ice were gigantic crystals, it is in the highest degree probable that the surface of the ice coincided with the basal plane, as was the case with the columnar crystals observed by Prof. Heim in the lake ice of the Swiss lowlands. For want of a polariscope we were prevented from investigating the matter further in the field; but in some small well sheltered pools on Tyrau Mawr we found it easy to produce the same phenomena of $p$ rcussion-figures, whilst the ice in the marshy places amongst the grass gave fractures of a most irregular kind. We found, in several places, skeleton-crystals like ornamented equilateral triangles, measuring some inches across.

THomas H. Holland.

Normal School of Science, South Kensington.

\section{Use of the R'mora in Fishing.}

WITH reference to Mr. A. C. Haddon's interesting account of the use of the Remora or sucker-fish by the natives of Torres Straits in fishing for turtles (NATURE, January 17, p. 285), I may call attention to the paper on this subject read by our corresponding member, Mr. Frederick Holmwood, C.B., late H. B.M. Consul at Zanzibar, before the Zoological Society of London, o. June I7, I88 I (see P.Z.S., I88I, P. 4II), which $\mathrm{Mr}$. Haddon does not seem to be acquainted with. $\mathrm{Mr}$. Holmwood has fully described the mode of the use of the R'enor $a$ by the native fishermen of Zanzibar in catching turtles and fishes. It is curious to find a somewhat similar method of employing the Remora practised by the islanders of. Torres Straits.

3 Hanover Square, London, W, January 19. P. L. Sclater.

\section{A Remarkable Rime.}

UNDER this heading a letter appears from Lutterworth (p. 27o), but no mention is made of the colour of the water obtained on melting some of the rime collected from the trees. In the neighbourhood, far removed from any large town, the rime crystals, on melting, gave water tasting very sonty, and looking as though the liquid had been used to wash Indian ink brushes in, it being quite black with sooty particles. M. H. MAW.

Barrow-on-Humber, Hull, January 22. 